\title{
In vitro Cytotoxic and Genotoxic Effects of Methanol and Aqueous Extracts of Gymnosporia Montana Plant
}

\author{
Nishat Ansari ${ }^{1}$ and Divya Chandel ${ }^{1 *}$ \\ ${ }^{1}$ Department of Zoology, BMT and Human Genetics, School of Sciences, Gujarat University, \\ Ahmedabad, India.
}

Authors' contributions

This work was carried out in collaboration between both authors. Author DC designed the experiment and drafted and revised the manuscript. NA has performed the experiments and wrote and revised the manuscript. Both authors read and approved the final manuscript.

Article Information

DOI: 10.9734/ARRB/2019/v31i530059

Editor(s):

(1) Dr. Moacir Marocolo Júnior, Professor, Physiology, Institute of Biological Sciences, Federal University of Juiz de Fora,
Brazil.

(2) Dr. George Perry, Dean and Professor of Biology, University of Texas at San Antonio, USA.

Reviewers:

(1) Mustafa Sevindik, Akdeniz University, Turkey (2) Moses Mwajar Ngeiywa, University of Eldoret, Kenya. (3) Oshim, Ifeanyi Onyema, Nnamdi Azikiwe University, Nigeria. Complete Peer review History: http://www.sdiarticle3.com/review-history/48400

Original Research Article

Received 22 January 2019

Accepted 08 April 2019

Published 18 April 2019

\section{ABSTRACT}

Introduction: Gymnosporia montana Benth. is a medicinal herb which has been valued in Ayurvedic medicine for its hepatoprotective effect. The plant has been studied for its pharmacological, antimicrobial, and antioxidant properties, but there are no reports on its genotoxicity.

Aim: Hence, in the present study, two extracts of $G$. montana (70\% methanolic and aqueous) at different concentrations were evaluated for the in vitro cytotoxicity and genotoxicity in Human peripheral blood lymphocyte cultures (PBLC) since these are well-established techniques for the analysis of the potentially mutagenic and carcinogenic chemicals.

Methodology: The 3-(4,5-dimethylthiazol-2-yl) -2,5-diphenyltetrazolium bromide (MTT), Mitotic index (MI), Sister-chromatid exchanges (SCEs), Cell cycle proliferative index (CCPI), Average 
generation time (AGT) and Population doubling time (PDT) were scored in cultures set up from 10 different healthy donors. The treatment of the cell culture was done employing different extracts of G. montana at three concentrations $(1.78 \mu \mathrm{g} / \mathrm{mL}, 3.57 \mu \mathrm{g} / \mathrm{mL}$ and $7.14 \mu \mathrm{g} / \mathrm{mL})$ with control and positive control (Ethyl methanesulfonate [EMS (1.93 mM)]).

Results: The MTT results showed the cytotoxic effect in a concentration-dependent manner in both the methanol and aqueous extract and the $\mathrm{IC}_{50}$ value of methanol and aqueous extract was found to be $2.63 \mu \mathrm{g} / \mathrm{mL}$ and $3.63 \mu \mathrm{g} / \mathrm{mL}$ respectively. The MI $(p<.001)$ and CCPI $(p<.05)$ in both the extracts showed significant values at higher concentration, but at lower and mid concentrations both the extracts were non-significant and the total SCEs, AGT and PDT in all the concentrations showed non-significant results when compared with the control.

Conclusion: These results indicate that the G. montana plant extracts at lower two concentrations showed no cytotoxicity and genotoxicity effects in cultured human peripheral blood lymphocytes. Therefore, we suggest that the plant extract is safe for use at the lower concentrations in traditional medicine.

Keywords: Gymnosporia montana; genotoxicity; cytotoxicity; cell viability; sister chromatid exchanges.

\section{INTRODUCTION}

Plants produce a diverse range of bioactive molecules making them a rich source of different types of herbal medicines. Plant-derived drugs remain an important resource, especially in developing countries, to overcome serious illnesses. Over $50 \%$ of all modern clinical drugs are made up of natural products which play an important role in drug development programs in the pharmaceutical manufacturing $[1,2]$ and many therapeutic substances have been extracted from medicinal plants and used during drug preparations $[3,4]$. Medicines manufactured from most plants in self-medication or through prescriptions fail to exhibit information on the toxicological profile or their safety and efficacy $[5,6]$. This is a fact of great concern since several studies have shown mutagenic [7-9] carcinogenic properties [10] and also the property of preventing carcinogenesis [11]. The interest of the public and the scientific community has increased in the benefit and harmful effect of the natural products and their uses in the last few decades [12,13].

Also, green plants in general, are a primary source of anti-mutagens as well as natural toxic agents [14]. Most of the herbal medicines are used without any standard safety and toxicological trials although the common assumption is that these products are non-toxic. However, this assumption is incorrect and dangerous, so toxicological studies should be done for herbal drugs [15]. Some investigations have revealed that many plants used as food or in traditional medicine have cytotoxic and genotoxic effects in vitro and in vivo assays $[16,17]$. The assessment of the possible toxicity of the medicinal plants, their extracts, or their constituents has been carried out on a relatively small number of plant species [18]. The claim that natural plant products are safe should be accepted only after the plant product passes through toxicity testing using modern scientific methods [19].

G. montana belonging to the family Celastraceae is found in South Africa, Nigeria, Tropical Africa, Mediterranean, Malaya, Australia, Arabia, Afghanistan, and India. It is a shrub or tree growing wild in dry areas and is commonly known as Vikalo in Gujarat, India, where it has been traditionally used in treating the ulcer, jaundice, gastrointestinal disorders, toothache, dysentery, and antispasmodic effect [20]. The previous study by Patel et al. [21] indicates that the extract of $G$. montana possesses significant hepatoprotective activity. A literature survey also showed that plant extracts can be mutagenic as well as antimutagenic depending on the test system used which indicates that a battery of assays are needed before any conclusion can be reached. Since the $G$. montana plant has not been investigated yet for cytotoxicity and genotoxicity, this study was undertaken to evaluate the plant by using its two different extracts i.e. $70 \%$ methanolic extract and an aqueous extract. Since the short-term tests for genotoxicity are typically used to identify potential mutagens and carcinogens, the leaf extracts of $G$. montana were studied for toxicity in cultured human peripheral blood lymphocytes using MTT, mitotic index (MI), sister chromatid exchanges (SCEs), cell cycle proliferative index (CCPI), average generation time (AGT) and population doubling time (PDT), as Peripheral Blood Lymphocyte cultures (PBLC) are a well 
established method to examine the genotoxic damage.

\section{MATERIALS AND METHODS}

\subsection{Collection of Plant Materials and Extract Preparation}

The leaves of $G$. montana were collected from a nursery in sector-30 of Gandhinagar. The taxonomic identity was authenticated and herbarium sheet with reference No. PH/14/0010 was deposited in Department of Pharmacognosy, K.B. Institute of Pharmaceutical Education and Research, Gandhinagar, India. The compounds in the leaves of $G$. montana was extracted according to our previous study [22] and after performing MTT and Ml, the three different concentrations: Low dose $(1.78 \mu \mathrm{g} / \mathrm{mL})$, Mid dose $(3.57 \mu \mathrm{g} / \mathrm{mL})$ and High dose $(7.142 \mu \mathrm{g} / \mathrm{mL})$ were finalized for further studies. Both the methanolic and aqueous extracts were analyzed at these concentrations for their cytotoxic and genotoxic effect using different parameters as mentioned below.

\subsection{Chemicals and Reagents}

All chemicals utilized in the following parameters were procured from Merck, Germany (AR Grade), while media and culture reagents were procured from HiMedia and Sigma Aldrich, USA (Culture Grade).

\subsection{Protocols}

The present study was approved by the Institutional Ethical Committee (IEC) of Gujarat University, Ahmedabad, India and 10 healthy individuals free from any infection, addiction (including tobacco, drug or alcohol abuse and non-smoking) between 20-30 years of age were recruited. Blood collection was carried out according to ethical guidelines and with prior consent of the subjects. Venous blood was collected from each donor in heparinized vacutainer and mixed gently to avoid blood clotting.

\subsection{Cell Viability Assay (MTT Assay)}

A quantitative colorimetric assay for mammalian cell survival and cell proliferation was assayed by the method of Mosmann [23] with slight modifications. An equal amount of Hicep and blood was taken in Tarson tubes and the WBC layer was separated for further use. $1.5 \mathrm{~mL}$ media, $20 \mathrm{ul} \mathrm{PHA}$, and varying doses ranging from $0.50 \mu \mathrm{g} / \mathrm{mL}$ to $10 \mu \mathrm{g} / \mathrm{mL}$ of the plant extract were added to $100 \mathrm{ul}$ of the sample and EMS $(1.93 \mathrm{mM})$ was used as a positive control. The cultures were incubated for 72 hours and harvesting was done on the $3^{\text {rd }}$ day. After addition of MTT [3-(4,5-dimethylthiazol-2-yl)-2,5diphenyltetrazolium bromide] (30 ul) the cultures were further incubated for 4 hours at $37^{\circ} \mathrm{C}$. DMSO was added to the pellet to observe a color change. The samples were centrifuged and the optical density was measured at $570 \mathrm{~nm}$ on Epoch Biotek.

\subsection{Mitotic Index (MI)}

Initially, the cultures were set up as per the standard protocol [24] at different concentrations and $\mathrm{MI}$ was done to finalize the three doses used in this study. By quantifying aspects of a dividing cell population, one can examine how cells differ in their capability to divide under different experimental conditions. Mitotic index is defined as the ratio between the number of cells in mitosis and the total number of cells. A total of 1000 cells were scored for each individual according to the following formula.

Mitotic index $(\mathrm{MI})=($ Number of dividing cells / Total number of cells) $\times 100$

\subsection{Sister Chromatid Exchanges (SCEs)}

Peripheral blood lymphocyte cultures were prepared according to the standard procedure [24] with slight modifications and for SCEs, 80 $\mathrm{\mu l}$ of Bromodeoxyuridine $(1 \mathrm{mg} / \mathrm{mL}$, BrdU) was added at $0^{\text {th }}$ hour [25] and cultures were incubated in dark at $37^{\circ} \mathrm{C}$ in an incubator and were harvested at 72 hours after colchicine treatment at the $69^{\text {th }}$ hour and slides were prepared. Cleaned slides were prepared by adding 3 to 4 drops of the cell suspension uniformly on a chilled slide and were flame dried. For Sister Chromatid Differentiation, the slides were stained with Hoechst 33258 for 20 min in the dark and layered with $2 \mathrm{X}$ saline sodium citrate buffer. The slides were then kept in UV exposure for $45 \mathrm{~min}$ in a moist chamber, washed in water and stained in $2 \%$ Giemsa for 5 min and were analyzed for SCEs, CCPI, AGT and PDT.

\subsection{Analysis of Sister Chromatid Exchanges (SCEs)}

Metaphases in the second cycle of cell division (M2) were selected for scoring on the basis of the spreading of chromosomes and 
differentiation of chromatids. Total exchanges were counted in $30 \mathrm{M} 2$ cells to calculate SCE/Plate and SCE/Chromosome to evaluate the level of Genotoxicity [26] using the following formula:

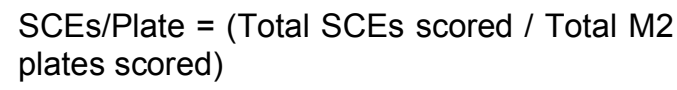

\subsection{Analysis of Cell Cycle Proliferative Index (CCPI)}

Differentially stained slides were scored for the proliferative kinetics based on the staining pattern of chromosomes. Total 100 metaphases were analyzed for each individual, classifying them on the first (M1), second (M2), third (M3) generation cells. At least 100 metaphases from each culture were analyzed for CCPI [26].

The cell cycle proliferative index (CCPI) for each individual was calculated according to the following formula:

$$
\mathrm{CCPI}=1(\mathrm{M} 1 \text { plate })+2(\mathrm{M} 2 \text { plate })+3(\mathrm{M} 3
$$$$
\text { plate) / } 100 \text { (Total plates) }
$$

\subsection{Analysis of Average Generation Time and Population Doubling Time}

The cell cycle time AGT is also studied as the ratio of the BrdU time and proliferative index (CCPI)

$$
\mathrm{AGT}=72 \text { hours (BrdU time) } / \mathrm{CCPI}
$$

And, the PDT is the time in which the cell divides, i.e. 24 hours

$$
\text { PDT = } 24 \text { hours } / \mathrm{CCPI}
$$

\subsection{Statistical Analysis}

Values of all the data are expressed as Mean \pm Standard Error of the 10 replicates. The statistical analysis was done in GraphPad Prism 6.0 software. A t-test was done to compare two groups while One-way ANOVA was done by Tukey's multiple comparison tests to compare more than two groups and significance was accepted when $p<.05$.

\section{RESULTS}

In the present study, the cells showed growth inhibition in a dose-dependent manner with a significant increase $(p<.001)$ in the percent cell inhibition when treated with two different extracts of $G$. montana at concentrations ranging from $0.50 \mu \mathrm{g} / \mathrm{mL}$ to $10 \mu \mathrm{g} / \mathrm{mL}$ (Table 1.A and 1.B). The percentage of dead cells in the methanol extract for each concentration was found to be 45.6, 48.77, 53.1, 57.5, 67.2, 68.4, 76.6, 77.8, 79.47, $83.9,88.3$ and in aqueous was found to be 42.2 , 47.6, 48.7, 51.7, 51.8, 56.5, 63.5, 71.4, 75.5, 78.262, 78.7. The $\mathrm{IC}_{50}$ value of $\mathrm{G}$. montana was found to be $2.63 \mu \mathrm{g} / \mathrm{mL}$ in methanol and 3.63 $\mu \mathrm{g} / \mathrm{mL}$ in aqueous extract.

From the prepared slides, dividing and nondividing cells were counted to determine the mitotic index for the assessment of the cytotoxicity in the control, positive control and plant extracts at different concentrations (Low Dose (LD): $1.78 \mu \mathrm{g} / \mathrm{mL}$, Mid Dose (MD): 3.57 $\mu \mathrm{g} / \mathrm{mL}$ and High Dose (HD): $7.14 \mu \mathrm{g} / \mathrm{mL}$ ). Table 2 shows the mean and standard error of the $\mathrm{MI}$ rates of control $(3.22 \pm 0.167983)$ and the positive control $(1.52 \pm 0.099849)$. The $\mathrm{Ml}$ of the three concentrations of methanol extract was 2.59 $\pm 0.114051,2.53 \pm 0.140774$ and $1.65 \pm 0.126802$ and aqueous extract was found to be $2.56 \pm 0.161499,2.48 \pm 0.11243$ and 1.6 \pm 0.142307 . For $\mathrm{MI}$, the extracts (both methanol and aqueous) showed a non-significant decrease in LD and MD whereas, highly significant $(p<.001)$ decrease was seen in the HD when it was compared with control values. Compared to the MI value of the positive control, a highly significant increase $(p<.001)$ in LD and $\mathrm{MD}$ and a non-significant increase in $\mathrm{HD}$ in methanol extract were seen. On the other hand, the aqueous extract showed a significant increase $(p<.05)$ in LD and MD, but a nonsignificant increase in the HD.

Our analysis showed that the total SCEs were non-significantly increased in all the concentrations when both the extracts (methanol and aqueous) were compared with the control group (Table 3 ). Also, on comparison with the positive control, both the extract showed highly significant $(p<.001)$ decrease in LD, but significant $(p<.01)$ decrease in MD and HD. (Table 3). As shown in Table 4, Cell cycle proliferative index (CCPI) showed a nonsignificant decrease in LD and MD but significant $(p<.05)$ decrease in HD when compared with control in both the extracts. Whereas, in comparison with the positive control, significant $(p<.05)$ increase in LD and MD and nonsignificant $(p<.05)$ increase in HD was seen. The AGT and PDT were non-significantly elongated 
Table 1. A. Cytotoxicity of G. montana in methanol and aqueous extract

\begin{tabular}{lll}
\hline $\begin{array}{l}\text { Concentration } \\
(\boldsymbol{\mu g} / \mathbf{~ m L})\end{array}$ & $\begin{array}{l}\text { \% Cell inhibition } \\
\text { (Methanol extract) }\end{array}$ & $\begin{array}{l}\text { \% Cell inhibition } \\
\text { (Aqueous extract) }\end{array}$ \\
\hline 0.50 & 45.6 & 42.2 \\
1 & 48.77 & 47.6 \\
2 & 53.1 & 48.7 \\
3 & 57.5 & 51.7 \\
4 & 67.2 & 51.8 \\
5 & 68.4 & 56.5 \\
6 & 76.6 & 63.5 \\
7 & 77.8 & 71.4 \\
8 & 79.47 & 75.5 \\
9 & 83.9 & 78.262 \\
10 & 88.3 & 78.7 \\
$\mathrm{IC}_{50}$ VALUE & 2.63 & 3.63 \\
\hline \multicolumn{2}{c}{} & Each value is represented as Mean \pm SE, $n=10$ \\
& Aqueous Extract vs Methanol Extract: ${ }^{* * * *}=p<.0001$ & (Highly significant)
\end{tabular}

Table 1. B. Cell viability of $G$. montana in methanol and aqueous extract

\begin{tabular}{|c|c|c|}
\hline Concentration $(\mu \mathrm{g} / \mathrm{mL})$ & Cell viability (Methanol extract) & Cell viability (Aqueous extract) \\
\hline 0.50 & 54.40 & 57.80 \\
\hline 1 & 51.23 & 52.40 \\
\hline 2 & 46.90 & 51.30 \\
\hline 3 & 42.50 & 48.30 \\
\hline 4 & 32.80 & 48.20 \\
\hline 5 & 31.60 & 43.50 \\
\hline 6 & 23.40 & 36.50 \\
\hline 7 & 22.20 & 28.60 \\
\hline 8 & 20.53 & 24.50 \\
\hline 9 & 16.10 & 21.74 \\
\hline 10 & 11.70 & 21.30 \\
\hline
\end{tabular}

Table 2. Mitotic index (M.I \%) of control and treated cultures

\begin{tabular}{|c|c|c|}
\hline Groups & Mitotic index of ME & Mitotic index of $\mathrm{AE}$ \\
\hline Control & $3.22 \pm 0.167983$ & $3.22 \pm 0.167983$ \\
\hline Low dose methanol extract $(1.78 \mu \mathrm{g} / \mathrm{mL})$ & $2.59 \pm 0.114051^{\mathrm{NS},}$ & $2.56 \pm 0.161499^{\mathrm{NS}}, \#$ \\
\hline MID dose methanol extract $(3.57 \mu \mathrm{g} / \mathrm{mL})$ & $2.53 \pm 0.140774^{\mathrm{NS}, \ldots}$ & $2.48 \pm 0.11243^{\mathrm{NS}, \#}$ \\
\hline High dose methanol extract $(7.14 \mu \mathrm{g} / \mathrm{mL})$ & $1.65 \pm 0.126802^{x \pi x}, \mathrm{~ns}$ & $1.6 \pm 0.142307^{\pi \times \pi}, \mathrm{ns}$ \\
\hline Positive control (1.93 mM) & $1.52 \pm 0.099849^{\times x \pi}$ & $1.52 \pm 0.099849^{\mathrm{max}}$ \\
\hline
\end{tabular}
HD: High Dose

in all the concentrations when they were compared with control (Table 4).

\section{DISCUSSION}

Special attention must be paid to the evaluation of the safety, efficacy, and quality of natural products and their components and it is important to determine the toxic effect of plant extracts used as herbal therapy on humans. In our study, we took a step towards exploring the cytotoxic and genotoxic effects of a herbal plant G. montana, since it is being used as an alternative medicine locally to cure jaundice and has a hepatoprotective effect $[20,21]$. Previously by Bhavita and coworkers [20], the leaf of $G$. montana was evaluated for pharmacognostical parameters and phytochemical screening, which 
Table 3. Showing total SCEs, SCEs/plate and SCEs/chromosome in control and treated cultures

\begin{tabular}{|c|c|c|c|c|}
\hline Extracts & Groups & Total SCEs & SCEs /plate & SCEs/ chromosome \\
\hline & Control & $90.1 \pm 3.03332$ & $2.999763 \pm 0.102211$ & $0.065212 \pm 0.002222$ \\
\hline \multirow[t]{3}{*}{ Methanol extract } & \multirow{3}{*}{$\begin{array}{l}\text { Low dose } \\
(1.78 \mu \mathrm{g} / \mathrm{mL}) \\
\text { Mid dose } \\
(3.57 \mu \mathrm{g} / \mathrm{mL}) \\
\text { High dose } \\
(7.14 \mu \mathrm{g} / \mathrm{mL})\end{array}$} & $\begin{array}{l}91.2 \pm 3.761551 \\
\text { NS, \#\# }\end{array}$ & $\begin{array}{l}3.042233 \pm 0.1242 \\
\text { NS, \#\#\# }\end{array}$ & $\begin{array}{l}0.066136 \pm 0.0027 \\
\text { NS, \#\#\# }\end{array}$ \\
\hline & & $\begin{array}{l}94.7 \pm 4.011352 \\
\text { NS, \#\# }\end{array}$ & $\begin{array}{l}3.153752 \pm 0.124359 \\
\text { NS, \#\# }\end{array}$ & $\begin{array}{l}0.06856 \pm 0.00288 \\
\text { NS, \#\# }\end{array}$ \\
\hline & & $\begin{array}{l}107.1 \pm 4.062072 \\
\text { NS, \#\# }\end{array}$ & $\begin{array}{l}3.599726 \pm 0.145142 \\
\text { NS, \#\# }\end{array}$ & $\begin{array}{l}0.078255 \pm 0.003155 \\
\text { NS, \#\# }\end{array}$ \\
\hline \multirow[t]{3}{*}{ Aqueous extract } & \multirow{3}{*}{$\begin{array}{l}\text { Low dose } \\
(1.78 \mu \mathrm{g} / \mathrm{mL}) \\
\text { Mid dose } \\
(3.57 \mu \mathrm{g} / \mathrm{mL}) \\
\text { High dose } \\
(7.14 \mu \mathrm{g} / \mathrm{mL})\end{array}$} & $\begin{array}{l}\text { 91.8 } 5.603242081 \\
\text { NS, \#\# }\end{array}$ & $\begin{array}{l}\text { 3.062538 } \\
\text { NS, \#\# }\end{array}$ & $\begin{array}{l}0.066577 \pm 0.00418228 \\
\text { NS, \#\# }\end{array}$ \\
\hline & & $\begin{array}{l}97.4 \pm 3.739001389 \\
\text { NS, \#\# }\end{array}$ & $\begin{array}{l}3.245319 \pm 0.162222711 \\
\text { NS, \#\# }\end{array}$ & $\begin{array}{l}0.07055 \pm 0.002703465 \\
\text { NS, \#\# }\end{array}$ \\
\hline & & $\begin{array}{l}108.1 \pm 3.303726066 \\
\text { NS, \#\# }\end{array}$ & $\begin{array}{l}3.603992 \pm 0.110085075 \\
\text { NS, \#\# }\end{array}$ & $\begin{array}{l}0.078348 \pm 0.002393154 \\
\text { NS, \#\# }\end{array}$ \\
\hline
\end{tabular}

Values are Mean $\pm S . E ;$ Control vs $L D, M D, H D$ and $P C:^{* * *}=p<.001$ and NS=Non-Significant; Positive Control (Ethyl Methanesulfonate) vs $L D$, MD and HD: \#\#<.01 and \#\#\#=p<.001; LD: Low Dose, MD: Mid Dose, HD: High Dose

Table 4. Showing CCPI, AGT, and PDT in control and treated cultures

\begin{tabular}{|c|c|c|c|c|}
\hline Extracts & Groups & CCPI & AGT & PDT \\
\hline & Control & $2.145 \pm 0.0151$ & $33.5815625 \pm 0.2382$ & $11.19385417 \pm 0.07941$ \\
\hline \multirow[t]{3}{*}{ Methanol extract } & Low dose $(1.78 \mu \mathrm{g} / \mathrm{mL})$ & $2.13 \pm 0.01334^{\mathrm{NS}, \#}$ & $33.8147 \pm 0.2111^{\mathrm{NS}, \# \#}$ & $11.2715 \pm 0.0703^{\mathrm{NS}, \# \#}$ \\
\hline & Mid dose $(3.57 \mu \mathrm{g} / \mathrm{mL})$ & 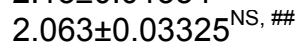 & $34.9882 \pm 0.6056^{\mathrm{NS}, \#}$ & $11.6627 \pm 0.2018^{\mathrm{NS}, \#}$ \\
\hline & High dose $(7.14 \mu \mathrm{g} / \mathrm{mL})$ & $1.901 \pm 0.0621^{*}, \mathrm{~ns}$ & $38.2796 \pm 1.3895^{\mathrm{NS}, \mathrm{ns}}$ & $12.7598 \pm 0.4631^{\mathrm{NS}, \mathrm{ns}}$ \\
\hline \multirow[t]{4}{*}{ Aqueous extract } & Low dose $(1.78 \mu \mathrm{g} / \mathrm{mL})$ & $2.084 \pm 0.0363^{\mathrm{NS}, \#}$ & $34.6549 \pm 0.6783^{\mathrm{NS}, \#}$ & $11.5516 \pm 0.2261^{\mathrm{NS}, \#}$ \\
\hline & Mid dose $(3.57 \mu \mathrm{g} / \mathrm{mL})$ & $2.075 \pm 0.0251^{\mathrm{NS}, \#}$ & $34.7453 \pm 0.4282^{\mathrm{NS}, \#}$ & $11.5817 \pm 0.1427^{\mathrm{NS}, \#}$ \\
\hline & High dose $(7.14 \mu \mathrm{g} / \mathrm{mL})$ & $1.895 \pm 0.06102^{\pi}, \mathrm{ns}$ & $38.3889 \pm 1.3733^{\mathrm{NS}, \mathrm{ns}}$ & $12.7963 \pm 0.4577^{\mathrm{NS}, \mathrm{ns}}$ \\
\hline & Positive control (1.93 mM) & $1.718 \pm 0.0693^{\mathrm{k \pi}}$ & $42.5220 \pm 1.7090^{* \pi}$ & $14.1740 \pm 0.5696^{\pi \pi}$ \\
\hline
\end{tabular}
\#\#p.01 and ns=Non-Significant; LD: Low Dose, MD: Mid Dose, HD: High Dose 
indicated that the leaf of G. montana was rich in phenol. In our previous study, we have tested the plant for its antioxidant activities in the two different extracts used here, which indicated that the G. montana plant is a good antioxidant [22]. The cytotoxic effect of these two leaf extracts of the plant at different concentrations was checked by doing the MTT assay, which is an appropriate method for screening new substances within a short period of time. The MTT assay has been described as a rapid, simple and reproducible method, widely used in the screening of drugs to measure the cytotoxic properties $[27,28]$. To be a high-quality drug candidate, the $\mathrm{IC}_{50}$ value of the tested compound should be sufficiently low to avoid any possible unspecific effects. The American National Cancer Institute assigns a significant cytotoxic effect of promising anticancer product for future bioguided studies if it exerts an $\mathrm{IC}_{50}$ value $<30 \mu \mathrm{g} / \mathrm{mL}[29,30]$. The cytotoxicity tests in the present study showed that $\mathrm{IC}_{50}$ of both the extracts were more or less similar and both the extracts showed a cytotoxic effect in a concentrationdependent manner. In similar studies, Varalakshmi and coworkers [31] found that neem extract has been cytotoxic to normal lymphocytes just like other chemotherapeutic agents at higher concentrations. Earlier studies hypothesized that the possible cytotoxic effect of plant extracts could be because of the presence of various phytochemicals such as alkaloids, flavonoids, tannins, phenolics, and glycosides [32-34]. Our results also showed a similar trend of response; as the concentration is increased, both the extracts showed cytotoxic properties and caused growth inhibition, thus indicating that cytotoxicity is possible in the human lymphocytes upon continued and unregulated consumption of these extracts at higher doses which can be related to a toxic effect on the metabolism of the cell or to DNA damage. Therefore, the traditional healers and patients should be enlightened of the risk of cytotoxicity that might arise from the use of extracts from this plant at high doses.

The Mitotic index (MI) was performed as it is a cytogenetic test, used to characterize proliferating cells and identify compounds that inhibit or induce mitotic progression. Results revealed a decrease in $\mathrm{Ml}$ values, which reflects the inhibition of progression of the cell cycle and/or loss of capacity to proliferate at high doses, which can be correlated with the earlier studies of $[27,28]$. But both the extracts were non-toxic at the LD and MD and only the HD showed significant results. Anything consumed in the higher amount would have a toxic effect. This reduction in MI was more evident at HD could be interpreted as cellular death [35] and related to the cytotoxic effect of the extracts. Both the extracts of $G$. montana are a mixture of different compounds like phenol, alkaloids, flavonoids, saponins, glycosides, and tannins and excess in any of these components may alter the cell cycle and can cause decreased $\mathrm{Ml}$ in a concentrationdependent manner.

The genotoxicity study was also performed as it describes the ability of chemical compounds and their metabolites to interact with DNA and/or the cellular machinery controlling the genome integrity [36]. Previous studies have shown that the genotoxicants interact either directly with DNA or chromosomes to produce DNA damage such as adducts, strand breaks, chromosome breakages, etc., or indirectly, disturbing the genomic integrity through several mechanisms, notably by interaction (1) with proteins involved in DNA replication, transcription, or repair, (2) with components of mitotic spindle, or (3) with protein kinases in charge of cell cycle checkpoints [37]. Genotoxicants are usually classified according to their mutagenicity, through the transformation of DNA damage into a mutation, clastogenicity, through modification of chromosome structure, and aneugenicity, through changes in the number of chromosomes (loss or gain) [38,39]. Genotoxicity evaluation of any substance or drug provides us a tool to analyze individual susceptibility to such chemicals and is thus found to have a direct relationship to cancer risk. No previous studies are available on genetic toxicology of the G. montana plant extract so present study was undertaken. Sister chromatid exchange analysis in human PBLC has often been applied as cytogenetic testing of potentially mutagenic and carcinogenic chemicals [40]. The SCE is generally a more sensitive indicator of genotoxic effects than structural aberrations [41] and it is a classic cytomolecular technique which provides an easy and accurate index to monitor DNA damage and DNA repair status, hence, this assay was performed to check out the effect of this plant extract on the human chromosomes. In the present study, no significant increases in SCE frequency in lymphocytes were detected in all the concentrations in both the extracts when compared with the control. An increased rate of SCEs could be a sign of persistent DNA damage [42], but the total SCEs, SCEs/plate and SCEs/chromosomes in the present study were almost similar to that of the control in all the doses (LD, MD, and HD). Therefore, both 
methanol and aqueous extracts may not promote DNA damage and are non-genotoxic in all the concentrations and they are not likely to affect the frequency of cytogenetic anomalies existing in peripheral lymphocytes in vitro. Since sister chromatid exchanges are extremely valuable and highly relevant endpoints for the detection of potential carcinogens, our results clearly indicate that the two extracts are non-carcinogenic. The failure of repair mechanisms to achieve recovery leads to DNA damage and strand breaks, resulting in an increase of SCEs frequencies $[43,44]$. Haytham and Nasser [45] showed the reduction in sister chromatid exchanges or change in the MI may be due to the direct action of the compounds present in the extract by inactivating it enzymatically or chemically.

The cell cycle kinetics was evaluated by the cell cycle proliferative index (CCPI), a parameter that represents the ratio of cells in the first, second and third mitosis and was gradually decreased in the present study similar to the results of MI for both the extracts, possibly due to an arrest of mitosis which allows the repair of genetic material. Cytotoxic effects occur in cells with a relatively high level of genetic damage [46]. We propose that the extract might be causing some DNA damage at $H D$ which gets repaired during the $G_{1}$ phase and hence no significant difference in SCEs values are observed. The significant decrease in cell cycle progression for HD observed in the present study would allow the DNA repair to take place. We suggest that no DNA damage is taking at the LD and MD, hence no extra time is required for DNA repair to take place in cell cycle and hence the cell cycle progression is similar to control values at these doses. Thus, we can say that the extracts are affecting the cells on higher consumption as MI and $\mathrm{CCPI}$, both at higher doses were affecting the cells by showing antimitotic properties but both LD and MD were having no cytotoxicity, which indicates that both the extracts did not have a significant cytotoxic effect on these parameters at the used lower two concentrations (LD and MD). It can be because medicinal herbs contain complex mixtures of thousands of compounds that can exert their antioxidant and free radical scavenging effect either separately or in synergistic ways [47]. Also, some bioactive compounds present in the plant can interfere with drug kinetics and produce adverse effects related or unrelated to their pharmacological actions, such as allergic reactions, mutagenic and carcinogenic effects. In this study, both the extracts affect cell proliferation by declining the
CCPI and cell progression by elongation of AGT and PDT in a concentration-dependent manner in comparison with control and positive control. The reduction in the mitotic activity and the cellcycle delay at higher doses could be attributed due to the formation of toxic DNA cross-links. These cross-links inhibit DNA replication and transcription, causing cell cycle arrest and induction of apoptosis [48]. The data obtained in the present study suggest that the compounds present in the extract of $G$. montana are not cytotoxic and not mutagenic at lower doses (LD and MD) and when treated cultures were compared to control and positive control, the values showed mitotic depression in all cultures, however, the values were non-significant. Thus, the plant extract is not harmful at the two lower tested levels (LD and MD) and can be safely used up to these doses and both the extracts are safe and non-toxic at these tested levels.

\section{CONCLUSIONS}

G. montana belonging to the family Celastraceae has been traditionally used in treating jaundice and has not been examined for cytotoxicity and genotoxicity till date. Evaluation of the endpoints described here would help to estimate the potential toxicity of this medicinal plant. The MTT findings indicate that cytotoxicity was aggravated with the increase in the concentration of both the leaf extracts of G. montana. The present in vitro investigations showed that the $\mathrm{MI}$ and $\mathrm{CCPI}$ for both the extracts of $G$. montana were almost similar to that of control at lower two concentrations (LD and MD), but at higher doses they produce cytotoxicity. The SCEs showed no genotoxic effect in all the three doses (LD, MD, and HD) of both the extracts. These observations specify that the $G$. montana plant extracts showed no cytotoxicity up to MD $(3.57 \mu \mathrm{g} / \mathrm{mL})$ and no genotoxicity effects at all the three doses (LD, MD, and HD) in cultured human peripheral blood lymphocytes. It is concluded that the methanol and aqueous extracts of $G$. montana is safe for use in humans and can be used at these doses in herbal medicine. Further in vitro and in vivo investigations are needed to confirm the results.

\section{CONSENT AND ETHICAL APPROVAL}

The present study was approved by the Institutional Ethical Committee (IEC) of Gujarat University, Ahmedabad, India and 10 healthy individuals free from any infection, addiction (including tobacco, drug or alcohol abuse and 
non-smoking) between 20-30 years of age were recruited. Blood collection was carried out according to ethical guidelines and with prior consent of the subjects. Venous blood was collected from each donor in heparinized vacutainer and mixed gently to avoid blood clotting.

\section{ACKNOWLEDGEMENT}

This study was supported by the Maulana Azad National Fellowship (MANF) grant from the University Grants Commission (UGC), New Delhi, India.

\section{COMPETING INTERESTS}

Authors have declared that no competing interests exist.

\section{REFERENCES}

1. Vedamurthy $A B$, Paarakh PM, Jogaiah S. Comparative study of antibacterial and antioxidant activity of fractionated plant extracts of amla [Phyllanthus emblica L.], tulsi [Ocimum tenuiflorum L.] and neem [Azadirachta indica $A$. juss]. European Journal of Biomedical and Pharmaceutical Sciences. 2015;2(3):253-259.

2. Sevindik $M$, Akgul $H$, Pehlivan $M$, Selamoglu Z. Determination of therapeutic potential of Menthalongifolia ssp. Iongifolia. Fresen Environ Bull. 2017;26:4757-4763.

3. Ouedraogo $M$, Baudoux $T$, Stevigny $C$, Nortier J, Colet JM, Efferth T, Qu F, Zhou J, Chan K, Shaw D, Pelkonen O, Duez P. Review of current and "omics" methods for assessing the toxicity (genotoxicity, teratogenicity, and nephrotoxicity) of herbal medicines and mushrooms. J Ethnopharmacol. 2012;140(3):492-512.

4. Pehlivan M, Sevindik M. Antioxidant and antimicrobial activities of salvia multicaulis. TURJAF. 2018;6(5):628-631.

5. Fernandes JBF, Vargas VMF. Mutagenic and antimutagenic potential of the medicinal plants M. laevigata and C. xanthocarpa. Phytoth. Res. 2003;17(3): 269-273.

6. Capasso R, Izzo AA, Pinto L, Bifulco T, Vitobello C, Mascolo N. Phytotherapy and quality of herbal medicines. Fitoterapia. 2000;71(1):58- 65.

7. Cardoso CRP, De SC, Bernardi IM, Sannomiya CC, Vilegas M, Varanda WEA. Mutagenic activity promoted by amento- flavone and methanolic extract of Byrsonima crassa Niedenzu. Toxicology. 2006;225(1):55-63.

8. Déciga-Campos $\mathrm{M}$, Rivero-Cruz I, Arriagaalba M, Castañedacorral G, Angeleslópez GE, Navarrete A, Mata R. Acute toxicity and mutagenic activity of Mexican plants used in traditional medicine. J. Ethnopharmacol. 2007;110(2): 334-342.

9. Mohd-Fuat A, Kofi E. Mutagenic and cytotoxic properties of three herbal plants from Southeast Asia. Trop. Biomed. 2007; 24(2):49-59.

10. Sá-Ferreira ICF, Vargas VMF Mutagenicity of medicinal plant extracts in Salmonella/ microsome assay. Phytoth. Res. 1999; 13(5):397-400.

11. Sarkar D, Sharma A, Talukder G. Plant extracts as modulators of genotoxic effects. Botanical Review. 1996;62(4):275300.

12. Pehlivan $M$, Mohammed FS, Sevindik $M$, Akgul H. Antioxidant and oxidant potential of Rosa canina. Eurasian $\mathrm{J}$ of Forest Sci. 2018;6(4):22-25.

13. Calapai G, Caputi AP. Herbal medicines: Can we do without pharmacologist? 2007; 4:41-43.

14. Plewa MJ, Wagner ED. Activation of promutagens by green plants. Annual Review of Genetics. 1993;27:93-113.

15. Kahaliw W, Hellman B, Engidawork E. Genotoxicity study of Ethiopian medicinal plant extracts on HepG2 cells. BMC Complementary and Alternative Medicine. 2018;18:45.

16. Celik TA, Aslant OS. Cytotoxic and genotoxic effects of Lavandula stoechas aqueous extracts. Biologia. 2007;62(3): 292-296.

17. Mohammed FS, Akgul $H$, Sevindik $M$, Khaled BMT. Phenolic content and biological activities of Rhuscoriaria var. zebaria. Fresen Environ Bull. 2018;27(8): 5694-5702.

18. Jordan SA, Cunningham DG, Marles RJ. Assessment of herbal medicinal products: challenges, and opportunities to increase the knowledge base for safety assessment. Toxicol Appl Pharmacol. 2010;243(2):198-216.

19. Jaykaran P, Bhardwaj, Kantnaria N, Madav $P$, Panwar $A$. The Internet Journal of Toxicology. 2009;6(1):1-6.

20. Dhru B, Patel B, Lakshmi B, Zaveri M. To evaluate anti-inflammatory and analgesic 
activity of leaf of gymnosporia moantana- a native of Gujarat American Journal of Pharmtech Research. 2011;1(3):227-237.

21. Patel PB, Patel TK, Shah P, Baxi SN, Sharma HO, Tripathi CB. Protective effect of ethanol extract of Gymnosporia montana (Roth) Bemth. in paracetamolinduced hepatotoxicity in rats. Indian Journal of Pharmaceutical Sciences. 2010; 72(3):392-396.

22. Ansari N, Chandel D. Antioxidant studies on methanol and aqueous extracts of gymnosporia montana plant. Int J Pharm Pharm Sci. 2019;11(2):65-70.

23. Mosmann T. Rapid colorimetric assay for cellular growth and survival: application to proliferation and cytotoxicity assays. J. Immunol. Methods. 1983;65:55-63.

24. Hungerford DA. Leukocytes cultured from small inocula of whole blood and the preparation of metaphase chromosomes by treatment with hypotonic $\mathrm{KCl}$. Stain Tech. 1965;40:333-338.

25. Perry P, Wolff S. New Giemsa method for the differential staining of sister chromatids. Nature. 1974;251:156-158.

26. Veniit S, Parry J. Mutagenicity testing: A practical approach. IRL Press, Oxford, Washington D.C. 1984;275-306.

27. Kasurka CB, Sekero ZA, Sekero LZ. Evaluation of the genotoxicity and cytotoxicity of fexofenadine in cultured human peripheral blood lymphocytes. Toxicol in vitro. 2011;25(7):1480-4.

28. Ligia MCB, Eliane PA, Ana BTM, Valter ADR. The viability of lymphocyte culture, at different times after blood collection, for karyotype analysis. J Bras Patol Med Lab. 2014;50(2):124-130.

29. Suffness M, Pezzuto JM. Assays related to cancer drug discovery. In: Hostettmann, K. (Ed). Methods in plant biochemistry: Assays for bioactivity. Academic Press, London. 1990;6:71-133.

30. Khakdan F, Khosro P. In vitro cytotoxic activity of aqueous root extract of Althea kurdica against endothelial human bone marrow cells (line k562) and human lymphocytes. Bull Env Pharmacol Life Sci. 2013;2(6):23-9.

31. Varalakshmi KN, Sangeetha CG, Samee US, Irum G, Lakshmi H, Prachi SP. In vitro safety assessment of the effect of five medicinal plants on human peripheral lymphocytes. Tropical Journal of Pharmaceutical Research. 2011;10(1):3340.
32. Sharma S, Kumar A, Namdeo AG. Pharmocognostical and phytochemical analysis of Nothapodytes nimmoniana stem. Int J Pharm Pharm Sci. 2012;4:4559.

33. Khan N, Kumar S, Singh RP, Ghankhar N. Preliminary phytochemical screening, fingerprinting and pharmacognostic evaluation of Nothapodytes nimmoniana leaves, stem and root collected from different geographical region. Res J Pharm Biol Chem Sci. 2012a;3:362-78.

34. Dixit A, Gayakwas S, Shirodkar A, Warkad S, Devlae A, Murthy S, et al. Phytochemical characterization and cells based analysis of bioactive components of Nothapodytes nimmoniana (J. graham). Int J curr Microbiol App Sci. 2015;2:18-37.

35. Rojas E, Herrera LA, Sordo M, Gonsebatt ME, Montero R, Rodriguez R, OstroskyWe. G. montanaan P Mitotic index and cell proliferation kinetics for the identification of antineoplastic activity. Anti- Cancer Drugs. 1993;4:637-640.

36. Butterworth BE. A classification framework and practical guidance for establishing a mode of action for chemical carcinogens. Regul Toxicol Pharmacol. 2006;45(1):923.

37. Magdolenova Z, Collins A, Kumar A, Dhawan A, Stone V, Dusinska M. Mechanisms of genotoxicity. A review of in vitro and in vivo studies with engineered nanoparticles. Nanotoxicology. 2014;8(3): 233-278.

38. Muller J, Decordier I, Hoet PH, Lombaert $\mathrm{N}$, Thomassen $\mathrm{L}$, Huaux $\mathrm{F}$, et al. Clastogenic and aneugenic effects of multiwall carbon nanotubes in epithelial cells. Carcinogenesis. 2008;29(2):427-433.

39. Botta A. Relations entre génotoxicité, mutagenèse et cancérogenèse. In: l'Environnement IPMdSd (ed) Journées Nationales de Santé au Travail dans le BTP. Service Hospitalo-universitaire de Médecine et Santé au Travail, Marseille. 2003;9-13.

40. Natarajan AT. Chromosome aberrations: past, present and future. Mutat Res. 2002; 504:3-16.

41. Nigroa MM, Palermob AM, Mudryc MD, Carballo MA. Cytogenetic evaluation of two nitroimidazole derivatives. Toxicology in vitro. 2003;17:35-40.

42. Cardoso RS, Takahashi-Hyodo S, Peitl P, Ghilardi-Neto T, Sakamoto-Hojo ET. Evaluation of chromosomal aberrations, 
micronuclei and sister chromatid exchange in hospital workers chronically exposed to ionizing radiation. Teratogen Carcin Mut. 2001;21:431-439.

43. Sonoda E, Sasaki MS, Morrison C, Yamaguchi-Iwai Y, Takata M, Takeda S. Sister chromatid exchanges are mediated by homologous recombination in vertebrate cells, Mol. Cell. Biol. 1999;19: 5166-5169.

44. Johnson RD, Jasin M. Sister chromatid gene conversion is a prominent doublestrand break repair pathway in mammalian cells, EMBO J. 2000;19:3398-3407.

45. Haytham MD, Nasser YA. Effect of Artemisia alba L. extract against ethinylestradiol induced genotoxic damage in cultured human lymphocytes. African
Journal of Biotechnology. 2012;11(86): 15246-15250.

46. Sordo M, Herrera LA, Ostrosky-*WeG. montanaan $\mathrm{P}$, Rojas $\mathrm{E}$. Cytotoxic and genotoxic effects of As, MMA, and DMA on leukocytes and stimulated human lymphocytes, Teratog Carcinog Mutagen. 2001;21:249-60.

47. Romero-Jimenez $M$, Sanchez $M$, Analla JC, Munoz-Serrano A. Genotoxicity and antigenotoxicity of some traditional medicinal herbs. Mutat. Res. 2005;585: 147-155.

48. Francesco Di, Ruggiero A, and Riccardi R. Cellular and molecular aspects of drugs of the future: Oxaliplatin. Cellular and Molecular Life Sciences. 2002;59(11): 1914-1927.

(c) 2019 Ansari and Chandel; This is an Open Access article distributed under the terms of the Creative Commons Attribution License (http://creativecommons.org/licenses/by/4.0), which permits unrestricted use, distribution, and reproduction in any medium, provided the original work is properly cited.

Peer-review history:

The peer review history for this paper can be accessed here: http://www.sdiarticle3.com/review-history/48400 